\title{
The Impact of the Transition Radius Lower Flange-Web on Local Stress of Monorail Crane Girder
}

\section{Goran M. Cvijović}

Headmaster Aviation Academy Belgrade

Srđan M. Bošnjak

Full Professor

University of Belgrade Faculty of Mechanical Engineering
Wide flange I-beams with parallel flange contours, which are now predominantly used in production of monorail crane girders, are characterized by a relatively large radial transition between flange contour and rib contour. Therefore, the influence of the radius on the stress state, due to the local bending caused by the action of crane trolley wheels, is more pronounced in wide-flange I-beams (IPB) than in conventional (I) and mid-wide (IPE) I-beams. This paper presents the results of numerical-analytical and experimental research of local stresses in the lower flange-rib transition zone at wide flange I-beams. It was found that the highest values of the considered stresses occur at the start of the transition contour, and not in the fictive point of intersection of the rib contour and the upper contour of the lower flange, as stated in relevant literature and current technical regulations (standard SRPS EN 15011: 2014). In addition, research results show that the absolute values of local stresses on the lower and upper contours of the lower flange are not equal.

Keywords: wide flange I-beams, local bending, strength, FEM.

\section{INTRODUCTION}

The concept of a monorail girder, along which the crane wheels travel, has predominantly used classical I-beams with inclined flange contours for many decades. The incline, depending on the standard, ranges between $12 \%$ and $16.7 \%$. The transition radius from flange contour to rib contour is usually numerically equal to the rib thickness. For all conventional I-beam girders, the ratio of transition radius $(R)$ and flange thickness $(t)$ is $R / t \approx 0.6$, and $R / t \approx 1.4$ for mid-wide IPE I-beams with parallel flange contours. The observed ratio for wideflange I-beams with parallel flange contours (HE) depends on the dimensions of the cross-sectional area: for HE-A $300 R / t \approx 1.9$; for HE-A $1000 R / t \approx 1.0$; for HEB $300 R / t \approx 1.42$; for HE-B $1000 R / t \approx 0.83$. According to the presented ratios, we may conclude that the impact of the radius on the stress state in the transition zone is more pronounced in I-beams with parallel flange contours than in conventional I-beams. Current standard SRPS EN 15011:2014 [1] in Annex E defines the stress state caused by the action of crane trolley wheels on flange contour and thereby takes parallel flange contour I-beams type IPB and IPE, as well as I-beams with inclined flange contour (classical I-beams) into consideration. It neglects the influence of the transition radius in the zone of transition between the flange and the rib in parallel flange contour - cross section " $0-0$ *", Figure 1. Section " $0-0 *$ " is positioned on the extension

Received: May 2016, Accepted: June 2016

Correspondence to: Prof. Srdjan M. Bosnjak

Faculty of Mechanical Engineering,

Kraljice Marije 16, 11120 Belgrade 35, Serbia

E-mail: sbosnjak@mas.bg.ac.rs

doi:10.5937/fmet1704543C

(C) Faculty of Mechanical Engineering, Belgrade. All rights reserved of the rib contour, while the referent point, where stress state caused by local bending occurs, is placed on lower flange contour (point " 0 "). Furthermore, it is stated by the standard that the absolute values of local stresses on the lower and upper contours in the observed section are equal. Tensional stress values in points " 1 " and " 2 " are not the subject of this paper.

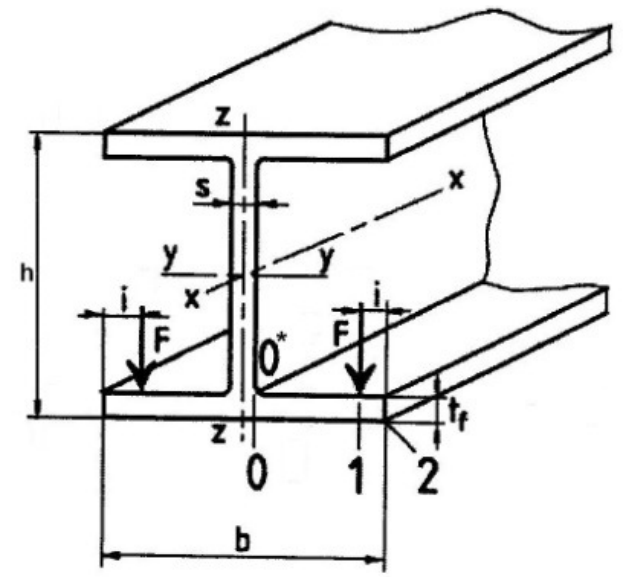

Figure 1. Cross-section points, referent points and loads on parallel contour I-beam [1]

With the significant impact of flange-to-rib transition zone for I-beams with parallel flanges in mind, we have considered the value of local stresses in the cross-section "0", determined in compliance with SRPS EN 15011:2014 standard. According to the mentioned standard, local stresses in longitudinal $(x)$ and transverse $(y)$ directions are determined in accordance with the following expressions,

$$
\sigma_{F x}=C_{x}(\lambda) \frac{F}{t_{f}^{2}},
$$




$$
\sigma_{F y}=C_{y}(\lambda) \frac{F}{t_{f}^{2}},
$$

where the parameter values of the wheel position $(\lambda)$ and stress coefficients $(\mathrm{C} x$ i $\mathrm{C} y$ ) are calculated according to the formula

$$
\begin{aligned}
& \lambda=\frac{i}{0.5(b-s)}, \\
& C_{x 0}=0.050-0.580+0.148 e^{3.015 \lambda}, \\
& C_{y 0}=-2.110-1.997+0.0076 e^{6.53 \lambda} .
\end{aligned}
$$

The remainder of this paper presents the results of a finite element analysis of local stresses in flange-to-rib transition zone and comparative analysis with the data in SRPS EN 15001:2014.

\section{FINITE ELEMENT ANALYSIS OF I-BEAM HE-A 360 WITH THE ASSUMED TRANSITION RADIUS OF $R=0$}

Finite element analysis has been carried out on a wideflange I-beam HEA-360: $h=350 \mathrm{~mm}, b=300 \mathrm{~mm}$, $t_{f}=17.5 \mathrm{~mm}, s=10 \mathrm{~mm}$, Figure 1 . The estimated domain has been discretized with different sizes of tetrahedral finite elements. Dimensions of finite elements in zone influenced by the local stresses (zone 1, Figure 2) are $2.5 \mathrm{~mm}, 5 \mathrm{~mm}$ in zone 2 , and $10 \mathrm{~mm}$ in zone 3 . The load $(2 \times 10 \mathrm{kN})$ is caused by the action of wheels (diameter $125 \mathrm{~mm}$ ), which are located at the distance $i=20 \mathrm{~mm}$ away from the edges of the free flange.

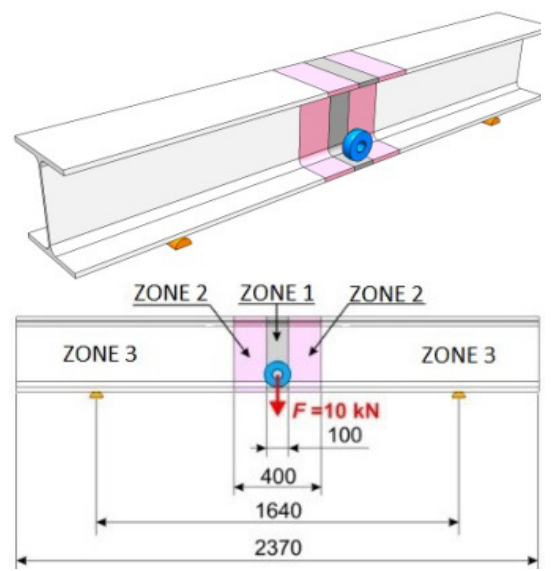

Figure 2. Model schematic

The maximum longitudinal stress value in the flange-to-rib transition zone occurs at the upper flange contour and is equal to $\sigma_{x, 5}^{*}=4.543 \mathrm{kN} / \mathrm{cm}^{2}$, while stress on the lower contour is equal to $\sigma_{x, 5}=-2.035$ $\mathrm{kN} / \mathrm{cm}^{2}$, Figure 3. Flange-to-rib transition zone for $R=0$ causes high stress concentration, where the value of the geometric concentration factor is:

$$
\alpha_{x, 5}=\frac{\sigma_{x, 5}^{*}}{\left|\sigma_{x, 5}\right|}=\frac{4.543}{|-2.035|}=2.232,
$$

which means that the value of the stress on the upper contour is $123.2 \%$ greater than the absolute stress value on the lower contour.

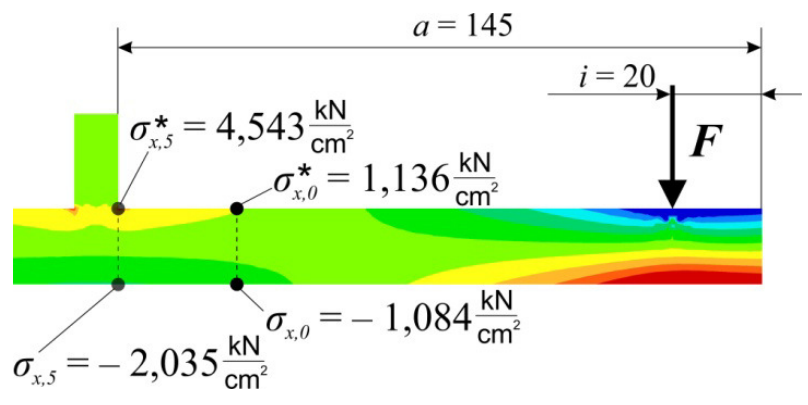

Figure 3. Local longitudinal stresses $(R=0)$

Stress field $\sigma_{y}$, Figure 4, suggests the existence of stress concentration in the transition zone. The value of the geometric concentration factor in the transverse direction is

$$
\alpha_{y, 5}=\frac{\sigma_{y, 5}^{*}}{\left|\sigma_{y, 5}\right|}=\frac{10.426}{|-7.697|}=1.355,
$$

where the stress value on the upper contour is $35.5 \%$ greater than the absolute value of stress on the lower contour.

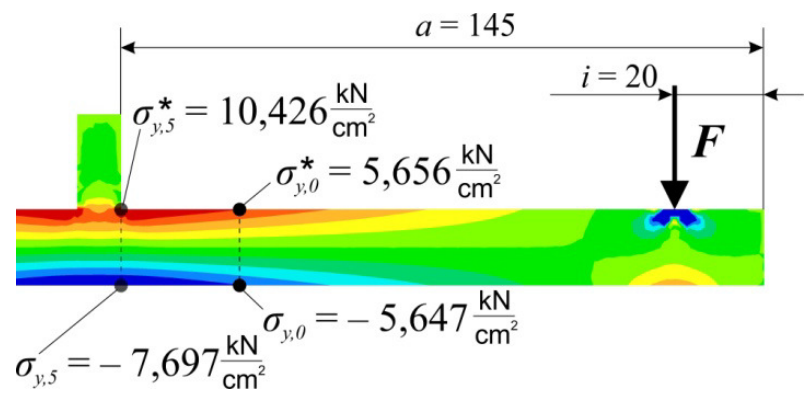

Figure 4. Local transverse stresses $(R=0)$

Accordingly, if we ignore the impact of the transition radius (i.e. $R=0$ ), we may notice significant difference between values of local stresses on the upper and lower contours, Figure 5, which is contrary to the results obtained with the application of SRPS EN 15011:2014 standard. Namely, for the basic geometric parameters of I-beam HE-A 360 , by applying the expressions (3)-(5), we obtain: $\lambda=0.138, C_{x 0}=0.194$, $C_{y 0}=-1.818$, respectively,

$$
\begin{aligned}
& \sigma_{F x 0}=C_{x 0} \frac{F}{t_{f}^{2}}=0.194 \frac{10.0}{1.75^{2}}=0.634 \mathrm{kN} / \mathrm{cm}^{2}, \\
& \sigma_{F x 0^{*}}=-0.634 \mathrm{kN} / \mathrm{cm}^{2}, \\
& \sigma_{F y 0}=C_{y 0} \frac{F}{t_{f}^{2}}=-1.818 \frac{10.0}{1.75^{2}}=-5.936 \mathrm{kN} / \mathrm{cm}^{2}, \\
& \sigma_{F y 0^{*}}=5.936 \mathrm{kN} / \mathrm{cm}^{2} .
\end{aligned}
$$

In addition to differences in stress values in the transition zone, the results of a finite element analysis indicate that the tensile stresses occur on the upper flange contour and compressive stresses occurs on the lower flange contour. Therefore, the results of a finite element analysis are in accordance with the results presented in [2-4] and, at the same time, in contrast with the results presented in $[5,6]$, on the basis of which the standard SRPS EN 15011:2014 was established. Based on the above-mentioned facts, we may conclude that the expression (4), defining the value of the stress coefficient $C_{x 0}$, is not correct. 


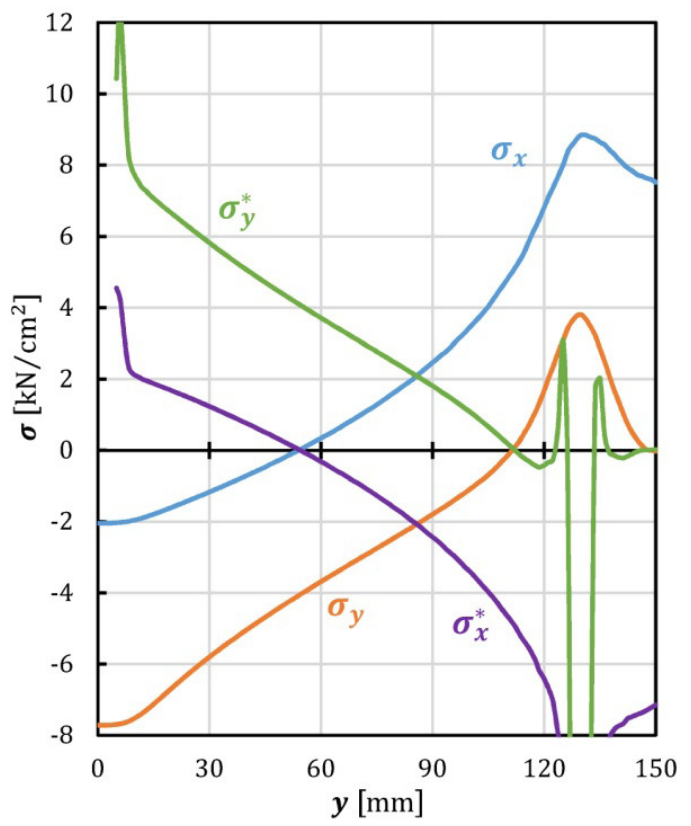

Figure 5. Local stresses on upper flange $\left(\sigma_{\mathrm{x}}{ }^{*}, \sigma_{\mathrm{y}}{ }^{\star}\right)$ and lower flange $\left(\sigma_{\mathrm{x}}, \sigma_{\mathrm{y}}\right)$ for $R=0$

In terms of local transverse stresses in the zone of transition, the results of a finite element analysis are in accordance with the results of all relevant authors [2-6] and the standard [1].

Comparison of the local longitudinal stress values, obtained with the finite element analysis and those obtained according to the standard would not be sensible, due to different stress characteristics. If we adopt stress values obtained by applying the standard as the basis for comparison, then the percentage differences in local transverse stress values are equal to

$$
\begin{aligned}
& \Delta \sigma_{y 0}=\frac{\left|\sigma_{F y 0}\right|-\left|\sigma_{y, 5}\right|}{\left|\sigma_{F y 0}\right|} 100= \\
& =\frac{|-5.936|-|-7.697|}{|-5.936|} 100=-34.2 \%, \\
& \Delta \sigma_{y 0^{*}}=\frac{\sigma_{F y 0}^{*}-\sigma_{y, 5}^{*}}{\sigma_{F y 0}^{*}} 100= \\
& =\frac{5.936-10.426}{5.936} 100=-75.7 \% .
\end{aligned}
$$

According to the expressions (12) and (13), we may conclude that the stress values obtained based on recommendations in the standard are lower than those obtained with the use of finite element method. Furthermore, it can be observed that the influence of the local stress concentration in the transverse direction already starts to diminish at a distance $\approx 10 \mathrm{~mm}$ away from flange-to-rib transition, Figure 4 . At the distance of $27 \mathrm{~mm}$ (corresponding to transition radius of an actual HE-A I-beams) local transverse stresses have the same absolute value of $\left(\sigma_{x, 0}^{*}=5.656 \mathrm{kN} / \mathrm{cm}^{2}\right.$; $\sigma_{x, 0}=-5.647 \mathrm{kN} / \mathrm{cm}^{2}$ ), which is $\approx 4.8 \%$ lower than the value obtained for cross-section " $0-0$ *" according to the standard.

\section{FINITE ELEMENT ANALYSIS OF AN ACTUAL I- BEAM HE-A 360 ( $R=27 \mathrm{~mm})$}

Based on the finite element model formed on the basis of the geometry of an actual I-beam HE-A 360 (all dimensions are the same as in model analysed in Section 2., except the transition radius $R=27 \mathrm{~mm}$ ) the identification of local stress state has been performed. Constraining of the model, continuum discretization, and loading the same as in model shown in Figure 2.

Local stress state in the referent cross-section of the flange-rib contour (cross section " $0-0$ *", according to the standard), is extremely low: $\sigma_{x, 5}^{*}=0.079 \mathrm{kN} / \mathrm{cm}^{2}$, $\sigma_{x, 5}=-0.891 \mathrm{kN} / \mathrm{cm}^{2}, \sigma_{y, 5}^{*}=0.054 \mathrm{kN} / \mathrm{cm}^{2}, \sigma_{y, 5}=$ $-3.982 \mathrm{kN} / \mathrm{cm}^{2}$, Figures 6 and 7. Those values of local stress are considerably lower than the values of stresses at the start of the transition radius of flange-rib profile, which equal to: $\sigma_{x, 0}^{*}=1.798 \mathrm{kN} / \mathrm{cm}^{2}, \sigma_{x, 0}=-1.410$ $\mathrm{kN} / \mathrm{cm}^{2}, \sigma_{y, 0}^{*}=7.136 \mathrm{kN} / \mathrm{cm}^{2}, \sigma_{y, 0}=-6.336 \mathrm{kN} / \mathrm{cm}^{2}$, Figures 6 and 7. The results shown above indicate that the referent cross-section in the transition zone should be positioned at the beginning of the transition radius.

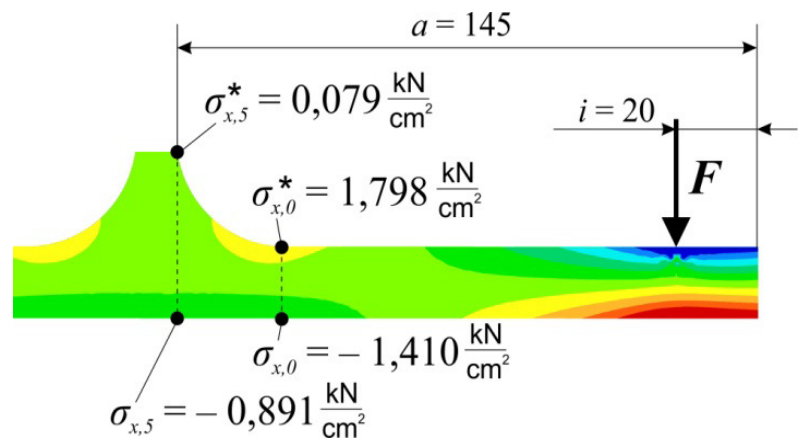

Figure 6. Local stress state in longitudinal direction $(R=27$ $\mathrm{mm}$ )

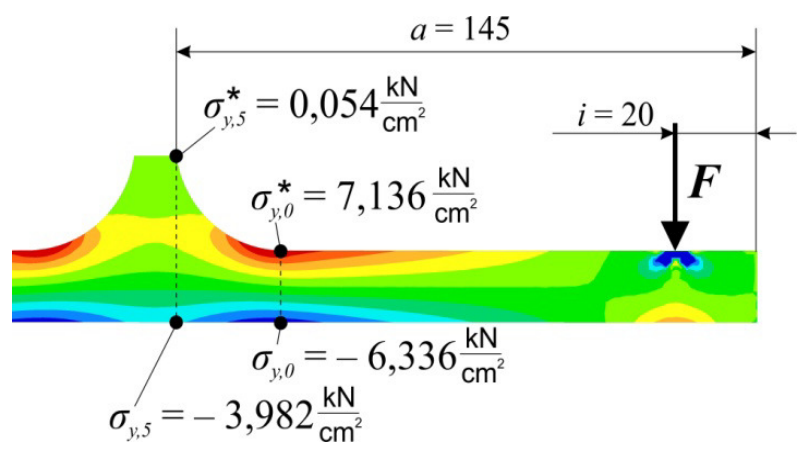

Figure 7. Local stress state in transverse direction $(R=27$ $\mathrm{mm}$ )

The values of geometric concentration factors of local stresses in the cross-section, corresponding to the beginning of the transition radius of the flange-rib profile, Figures 6 and 7,

$$
\begin{aligned}
& \alpha_{x, 0}=\frac{\sigma_{x, 0}^{*}}{\left|\sigma_{x, 0}\right|}=\frac{1.798}{|-1.410|}=1.275, \\
& \alpha_{y, 0}=\frac{\sigma_{y, 0}^{*}}{\left|\sigma_{y, 0}\right|}=\frac{7.136}{|-6.336|}=1.126,
\end{aligned}
$$


are considerably lower than the corresponding values of the geometric factor of local stress concentration for $R=0$, expressions $(6,7)$.

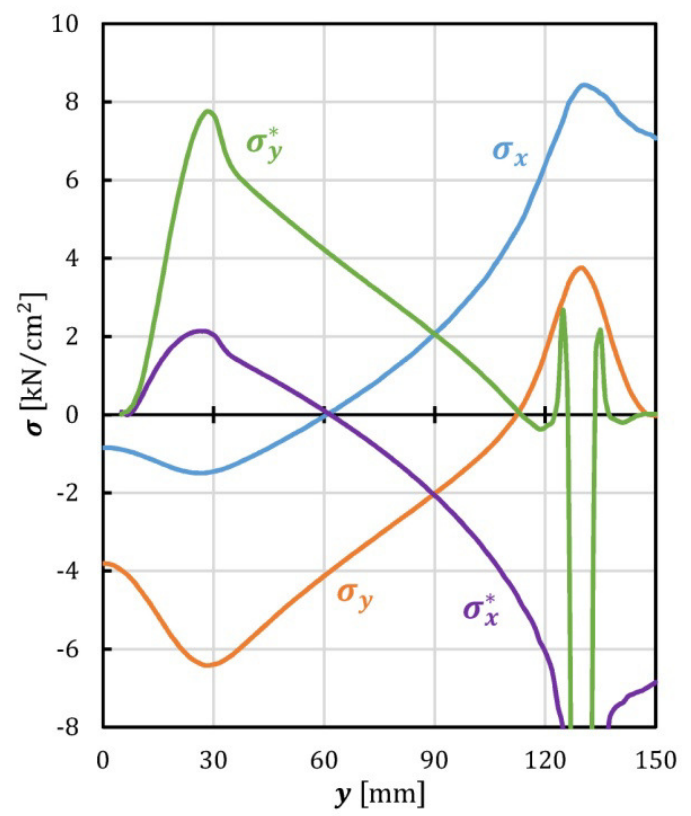

Figure 8. Local stress state in the upper $\left(\sigma_{x}{ }^{\star}, \sigma_{y}{ }^{\star}\right)$ and lower flange $\left(\sigma_{x}, \sigma_{y}\right)$ for $R=27 \mathrm{~mm}$

According to the presented results of a finite element analysis, we may conclude that the influence of the flange-to-rib transition radius is twofold: (1) it moves the cross-section with the greatest local impact, compared to the cross section " $0-0 *$ ", defined by the standard; (2) it reduces the difference in absolute values of stresses on the upper and lower flange contours.

It is important to note that local longitudinal stresses in point , 0 “ in the transition zone are compressive, Figure 8 , in contrast to those obtained with the procedure of identification of local longitudinal stresses presented in the standard.

If we adopt the stress values obtained by the standard as the basis for comparison, the percentage differences in local transverse stress value equal to

$$
\begin{aligned}
& \Delta \sigma_{y 0}=\frac{\left|\sigma_{F y 0}\right|-\left|\sigma_{y, 5}\right|}{\left|\sigma_{F y 0}\right|} 100= \\
& =\frac{|-5.936|-|-6.336|}{|-5.936|} 100=-6.74 \%, \\
& \Delta \sigma_{y 0^{*}}=\frac{\sigma_{F y 0}^{*}-\sigma_{y, 5}^{*}}{\sigma_{F y 0}^{*}} 100= \\
& =\frac{5.936-7.136}{5.936} 100=-20.22 \%,
\end{aligned}
$$

and they are considerably lower than the percentage differences determined for $R=0$, expressions $(12,13)$. Furthermore, the values of local stresses in the crosssection, for $R=27 \mathrm{~mm}$, determined by the application of the standard, are lower than the values obtained by finite element analysis, i.e. they are not on the side of safety.

\section{EXPERIMENTAL RESEARCH}

Tensometry research on the wide-flange IPB I-beam HE-A 360 were performed on the originally-designed test table, Figures 9 and 10.

Measuring points (MP) 6 and 7 are positioned on the upper flange contour in the transition zone, while MPs 9 and 10 are positioned on the lower flange contour, Figure 10. Based on the measurement results, and the application of equations for biaxial stress state, the values of local stress in transition zone have been calculated:

$$
\begin{aligned}
& \sigma_{x, l}^{M P 6-7}=2.2 \mathrm{kN} / \mathrm{cm}^{2} \\
& \sigma_{y, l}^{M P 6-7}=8.2 \mathrm{kN} / \mathrm{cm}^{2} \\
& \sigma_{x, l}^{M P 9-10}=-1.7 \mathrm{kN} / \mathrm{cm}^{2} \\
& \sigma_{x, l}^{M P 9-10}=-7.4 \mathrm{kN} / \mathrm{cm}^{2}
\end{aligned}
$$

Character of local stresses in the transition zone, determined by the results of a finite element analysis, expressions (Figure 6-8) correspond to the character of observed stresses determined by tensometry researche, expressions (18-21). Therefore, longitudinal stresses on the upper contour are tensile, and compressive on the lower contour, which confirms the statement from Section 2, that expression (4) for determining stress coeficient according to the standard [1], is not correct.

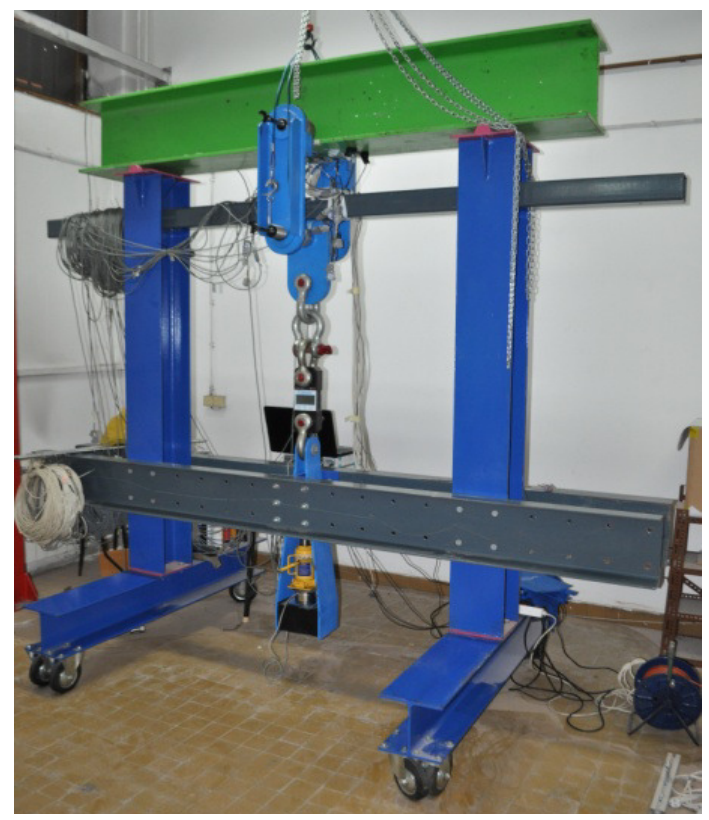

Figure 9. Test table

Deviations of experimental results compared to numerical values of certain local stresses are explained with the inevitable errors in the positioning of the strain gauges, and the material and geometric imperfections of the test girder. In addition, the stress values derived from the tensometry measurements were determined under the assumption that the values of modulus of elasticity and Poisson's ratio are $E=21000 \mathrm{kN} / \mathrm{cm}^{2}$ and $v=0.3$, respectively. Mendel, however, in his analysis of 
the experimental results, states $[3,4]$ that the possible variations of those materials' constants range between $\Delta E / E= \pm 0.05$ and $\Delta v / v= \pm 0.1$.

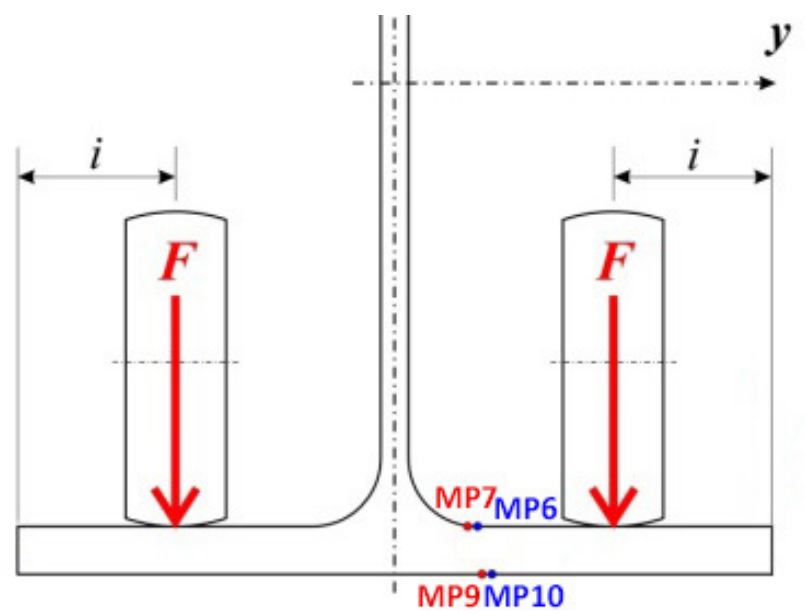

Figure 10. Measuring points

\section{CONCLUSION}

Based on the presented results of research, we may conclude that the transition radius of the flange-rib profile plays an important role in the distribution of stresses caused by local bending of loaded flange Ibeams with parallel contour flanges. Reflecting on the relevant standard SRPS EN 15011:2014 ("Crane Bridge and portal cranes") which, in Annex E, provides expressions and recommendations for the stress estimation caused by local bending of a single-flange crane girder, the aim of this research, whose brief overview has been presented in this paper, was to point out the following facts:

- The influence of the transition radius must be taken into account in the identification of local stresses in the transition zone;

- The character of local stresses in the longitudinal direction, determined by using the standard [1], does not correspond to the real nature of the said stresses;

- The values of local stresses in the transition zone, determined by using the standard [1] are lower than the values obtained by finite element analysis and tensometry measurements, which means that standard EN 15011: 2014 gives results that are not on the side of safety.

\section{ACKNOWLEDGMENT}

This work is a contribution to the Ministry of Education, Science and Technological Development of Serbia funded project TR 35006.

\section{REFERENCES}

[1] EN 15011:2011+A1:2014 - Cranes. Bridge and gantry cranes, European Committee for Standardization, 2014.

[2] Becker, K.: Trägerflanschbiegung durch Laufkatzen, Fördern und heben, vol. 18, no. 4, pp. 231234, 1968.

[3] Mendel G. Berechnung der Trägerflansch-beanspruchung mit Hilfe der Plattentheorie, Teil I: Die Kragplatte veränderlicher Dicke, Fördern und heben, vol. 22, no. 14, pp. 805-814, 1972.

[4] Mendel G. Berechnung der Träger-flanschbeanspruchung mit Hilfe der Plattentheorie, Teil II: Vergleich zwischen IPE und I Profil, Fördern und heben, vol. 22, no. 15, pp. 835-842, 1972.

[5] Hannover H, Reichwald R. Lokale Biegebeanspruchung von Träger-Unterflanschen, Teil I, Fördern und heben, vol. 32, no. 6, pp. 455-460, 1982.

[6] Hannover H, Reichwald R. Lokale Biegebeanspruchung von Träger-Unterflanschen, Teil II, Fördern und heben, vol. 32, no. 8, pp. 655-660, 1982.

\section{УТИЦАЈ РАДИЈУСА ТРАНЗИЦИЈЕ ДОЊИ ПОЈАС-РЕБРО НА ЛОКАЛНЕ НАПОНЕ}

\section{Г. Цвијовић, С. Бошњак}

Широкопојасне профиле са паралелном контуром појасева, који се данас доминантно користе за израду једношинских носача дизалица, карактерише релативно велики радијус транзиције контуре појаса у контуру ребра. Управо због тога, утицај поменутог радијуса на напонско стање изазвано локалним савијањем услед дејства точкова дизаличних колица знатно је израженији код широкопојасних (IPB) профила, у односу на класичне I профиле и средње широке (IPE) профиле. У раду су презентирани резултати нумеричко-аналитичког и експерименталног истраживања локалних напона у зони транзиције доњи појас/ребро код широкопојасних профила. Утврђено је да се највеће вредности разматраних напона јављају на почетку транзиције контуре, а не у тачки фиктивног пресека контуре ребра и доње контуре доњег појаса, како се наводи у релевантној литератури и актуелној техничкој регулативи (стандард EN 15011:2014). Осим тога, резултати истраживања доказују да апсолутне вредности локалних напона на доњој и горњој контури нису једнаке. 